\title{
KRITIK ABDUL KARIM \\ AMRULLAH TERHADAP RĀBIȚAH DI MINANGKABAU DALAM TAFSIR AL-BURHĀN
}

\author{
Helfi \\ Institut Agama Islam Negeri Bukittinggi Sumatera Barat, Indonesia \\ E-mail: helfibkt@yahoo.co.id
}

\begin{abstract}
This article explores the thought of Abdul Karim Amrullah on the issue of rabitah in Minangkabau. He is regarded as very critical in responding social and cultural life, especially relating to tarekat. All behaviors of society should have basis from the Qur'an and Sunnah. All acts which are not based on the Qur'an and Sunnah are considered as innovation (bid'ah) that should be avoided. Amrullah categorically rejected räbitah for there was no shari'a basis for it, although the kaum tua (conservative) in Minangkabau attempted to conserve räbitah in their surau. Räbitah as one of wasilah (mediator) is understood as a medium to reach God through substitute face. What is meant is the murshid who taught their followers to achieve the determined position in their own tarekat. Amrullah's criticism towards räbitah in Minangkabau initially resulted in resistence, especially among the founder of tarekat. However, in the course of time the issue of tarekat declined, and even underwent significant decay in Minangkabau.
\end{abstract}

Keywords: Abdul Karim Amrullah; tarekat; innovation; räbitah.

\section{Pendahuluan}

Awal abad ke-19, terjadi polemik akademik yang sangat tajam berkaitan dengan persoalan tarekat di Minangkabau, khususnya praktik tawassul melalui räbitah dalam seremonial tarekat. Kerasnya polemik tarekat tersebut kemudian berpengaruh terhadap terbelahnya ulama Minangkabau ke dalam dua kelompok besar, yaitu "golongan tua" dan "golongan muda". Gologan tua sebagai kelompok yang mempertahankan tradisi tarekat dan golongan muda yang melakukan rekonstruksi tarekat secara besar-besaran. Pertemuan dua pemikiran besar ini melibatkan ulama-ulama sentral di Minangkabau yang secara 
kasat mata dapat dipetakan kepada dua arus pemikiran, yaitu: pertama, Abdul Karim Amrullah sebagai tokoh muda yang terpengaruh dari konsep pembaruan yang disuarakan oleh Muhammad 'Abduh dan Muhammad Rashīd Riḍ̄a melalui Ahmad Khatib al-Minangkabawi. Kedua, Mungka (1857-1921 M) sebagai rival kelompok pertama dan ulama lain yang sealiran dengannya sebagai praktisi tarekat lokal di Minangkabau. Persoalan prinsip yang menjadi perseteruan dua arus pemikiran tersebut adalah perbedaan dalam memahami dalīl tentang räbitah, penafsiran ayat dan pandangan ulama tua dalam mempertahankan räbitah.

Kritik Abdul Karim Amrullah terhadap eksistensi ordo sufi sama apa yang dikritik oleh reformis Muslim lainnya, yaitu seruan terhadap supremasi otoritas al-Qur'ān, Sunnah Nabi, dan praktik keislaman yang dilakukan oleh generasi sesudahnya dengan meletakkan sejarah Islam masa lalu sebagai pola pembaruan. Ide-ide penafsiran yang dicanangkan Abdul Karim Amrullah bercirikan sebagai tafsir reformis yang kental mengkritik sosial budaya ketika berbenturan dengan Islam.

Kehadiran tarekat di ranah tasawuf tidak lepas dari upaya menjauhi kenikmatan dunia, baik berupa benda atau dalam bentuk pangkat. Reaksi menjauhi kehidupan dunia muncul dengan adanya gerakan zubd (asketisme) yang lahir pada abad kedua hijrah pada masa pemerintahan Dinasti Bani Umayyah. ${ }^{2}$ Faktor lain munculnya tasawuf adalah reaksi dari gerakan Mutakallimin yang dominan menggunakan akal untuk mengetahui Allah dan abai terhadap penggunaan rasa.

Kritik Abdul Karim Amrullah tentang räbitah ini diulas dalam tafsir al-Burbān-nya dan karya-karyanya yang lain yang berjumlah puluhan judul. Tafsir ini yang sebagai induk pemikiran Abdul Karim Amrullah dapat dipahami secara menyeluruh jika dilengkapi dengan tulisan-tulisan lainnya. Menurut Hamka, Tafsir al-Burbān yang ditulis Abdul Karim Amrullah ditulis tahun $1922^{3}$ yang merupakan tafsir Juz

\footnotetext{
${ }^{1}$ Dalïl dapat diartikan dengan sesuatu yang mampu mengantarkan sebuah kebenaran atau informasi kepada si sabjek. Dalil yang diperoleh dapat berbentuk qat ${ }^{t} \bar{l}$ atau zanni. Lihat 'Abd al-Karīm b. 'Alī b. Muhammad al-Namlah, al-Mubadhdhab fì $\mathrm{Tlm}$ Usūl al-Fiqh al-Muqāran, Vol. 2 (Riyad: Maktabat al-Rushd, 2008), 472.

2 M. Sanusi Latief, "Gerakan Kaum Tua di Minangkabau” (Disertasi--IAIN Syarif Hidayatullah, Jakarta, 1988), 80.

3 A. Sawabi Ichsan, dkk., Muqaddimah al-Qur'an dan Tafsirnya (Jakarta: Dewan Penyelenggara Pentafsiran al-Qur'an Departemen Agama RI, 1983), 73.
} 
'Amma dan selesai dicetak tahun 1927 di Drukkerijj Fort de Kock, Bukittinggi dengan mengikuti urutan Muṣhaf 'Uthmānī.

Keberanian Abdul Karim Amrullah "menggugat" räbitah di Minangkabau kemudian menimbulkan kegaduhan antara golongan tua dan golongan muda yang berimplikasi terhadap peninjauan kembali praktik räbitah dan menyusutnya tradisi räbitah yang saat itu telah berkembang di tengah-tengah masyarakat lokal.

\section{Perkembangan Tarekat di Minangkabau}

Lancarnya hubungan Indonesia dengan Timur Tengah berpengaruh terhadap menyebarnya aliran tarekat ke Indonesia. ${ }^{7}$ Menurut H. R. G. Gibb dan J. H. Kramers, tidak kurang dari 350 macam tarekat yang berkembang di negeri-negeri Islam, baik yang merupakan tarekat induk maupun cabang-cabangnya. ${ }^{8}$ Di Minangkabau sendiri, menurut M. Sanusi Latief, terdapat 41 nama tarekat yang bisa dikategorikan sebagai tarekat mu'tabarah, di antaranya adalah tarekat Naqshabandīyah-Khālidīyah, Qādirīyah, Shaț̣arīyah,

${ }^{4}$ Hamka, Ayabku: Riwayat Hidup DR. H. Abdul Karim Amrullab dan Perjuangan Kaum Agama di Sumatera (Jakarta: Ummida, 1982), 259.

5 Drukkerij merupakan bahasa Belanda yang berarti percetakan. Istilah drukkerij sebagai percetakan sudah dikenal Abdul Karim Amrullah ketika di Mekah yang digunakan oleh Muhammad Majid Kurdi atau mertua dari Shaykh Ahmad Khatib alMinangkabawi. Setelah Majid Kurdi wafat, drukkerij dikelola oleh anaknya yang bernama Hamid Kurdi. Masa Hamid Kurdi inilah kemudian Hamka sebagai anak Abdul Karim Amrullah juga mendapatkan pengalaman sebagai penyusun tulisan dalam bahasa Indonesia di sana. Lihat Hendri Chambert-loir, Naik Haji di Masa Silam Tabun 1900-1950, Vol. 2 (Jakarta: Gramedia, 1913), 687.

6 Belum ditemukan penafsiran lokal Minangkabau dengan pendekatan historika penurunan al-Qur'ān seperti tafsir yang ditulis oleh M. 'Izzat Darwazah (1888-1984 M) dengan al-Tafsìr al-Hadith-nya, 'Abd al-Qādir Malla Ḥuwaysh Āl al-Ghāzī al-'Ānī dengan al-Qasm al-Makkei min Tafsìr al-Qur'ān al-Ażim-nya dan Muhammad Ābid alJābirī (1935-2010 M) dengan Fahm al-Qur'ān al-Häkim Tafsìr al-Wädịh Hasb Tartīb alNuฉūl. Al-Jābirī sendiri memiliki tafsir berdasarkan urutan turunnya al-Qur'ān yang berjumlah tiga jilid. Buku tafsir tersebut tidak hanya memuat tafsir saja, tapi juga membicarakan ilmu tafsir seperti naskh. Lihat Muhammad 'Ābid al-Jābirī, Fahm alQur'ān al-Häkim: Tafsìr al-Wädịh Hasb Tartīb al-Nuzūl (Beirut: Markaz Dirāsāt alWahdah al-Islāmīyah, 2008), 96.

7 Ajid Thohir, Gerakan Politik Kaum Tarekat: Telaab Historis Gerakan Politik Antikolonialisme Tarekat Qadiriyah-Naqshabandiyah di Pulau Jawa (Bandung: Pustaka Hidayah, 2002), 113.

${ }^{8}$ H. R. G. Gibb dan J.H. Kramers, Shorter Encyclopaedia of Islam (Leiden: t.tp., 1953), 575-578. 
Shādhilīyah, Dasūqīyah, Akhbarīyah, Badawīyah dan Samanīyah.' Berkembangnya tarekat di Minangkabau tidak lepas dari pengaruh Islam yang berada di Aceh, kemudian terus menjalar sampai ke Ranah Minang. Setelah berkembangnya tarekat di Minangkabau, kemudian varian tarekat mengerucut kepada tiga aliran tarekat yang terkenal pada abad kedelapan belas yaitu Naqshabandīyah, Shațtarīyah ${ }^{10}$ dan Qādirīyah. ${ }^{11}$

Di Minangkabau, tarekat Shațarīyah pertama kali diperkenalkan oleh Burhanuddin (wafat 1111 H/1699 M) di Tanjuang Medan, Ulakan, Pariaman. Selanjutnya tarekat ini dikembangkan di Minangkabau oleh Abdurrahman (1777-1899) yang terdapat di Batu Hampar, Lima Puluh Kota. Tarekat Sammaniyyah berkembang di Kumango, Tanah Datar yang dikembangkan oleh Abdurrahman Kumango. ${ }^{12}$

Begitu kuatnya pengaruh tarekat bagi ulama di Minangkabau hingga hampir semua ulama menjadi penganut, pengamal dan penyebar tarekat. Seorang ulama yang mengajar di surau, di samping mengajarkan al-Qur'ān, juga merangkap sebagai guru tarekat. ${ }^{13}$ Jika pengajian al-Qur'ān dan pengajian kitab diikuti oleh anak-anak dan

\footnotetext{
${ }^{9}$ Latief, Gerakan Kaum Tua di Minangkabau, 82-83.

10 Tarekat Shattarīyah didirikan oleh 'Abd Allah Shațāar, seorang sufi dari India yang wafat tahun $1426 \mathrm{M}$. kemudian terus menyebar hingga ke Sumatera dan Jawa melalui Abdurauf al-Sinkli (1617-1690). Lihat Nur Syam, Tarekat Petani Fenomena Tarekat Syattariyah Lokal (Yogyakarta: LKiS, 2013), 26. Tarekat Shațarīyah memiliki doktrin waḅdat al-wujüd yang dibawa oleh Abdurrauf al-Sinkli yang menerima ijazah dari guru tarekatnya yang bernama Ahmad al-Qushashī. Lihat Miftah Arifin, Sufi Nusantara: Biografi Karya Intelektual dan Pemikiran Tasawuf (Yogyakarta: Ar-Ruzz Media, 2013), 80.

11 Tarekat Qādirīyah dinisbatkan kepada 'Abd al-Qādir al-Jīlānī (471-561 H/10791166 M). Lihat Christine Dobbin, Kebangkitan Islam dalam Ekonomi Petani yang Sedang Berubah Sumatera Tengah 1784-1847 (Jakarta: INIS, 1992), 143. Lihat juga Oman Fathurahman, Tarekat Syattariyah di Minangkabau: Teks dan Konteks (Jakarta: Prenada Media Group, 2008), 25.

12 Latief, Gerakan Kaum Tua di Minangkabau, 86.

13 Penyebaran tarekat melalui lembaga surau di Minangkabau dapat dikatakan suatu kekhasan tersendiri dibanding perkembangan tarekat di daerah lain. Di Jawa misalnya, tarekat berkembang melalui lembaga pesantren tapi dapat dipastikan bahwa lebih banyak pesantren yang tidak mengembangkan tarekat dibanding dengan pesantren yang mengembangkan tarekat. Sebaliknya di Minangkabau, hampir semua basis surau sebagai lembaga pengembangan tarekat, baik tarekat Shațarīyah, Naqsyabandīyah atau Sammaniyah. Lihat Fathurahman, Tarekat Syattariyah di Minangkabau, 22.
} 
remaja, maka pengajian tarekat diikuti oleh orang-orang dewasa atau orang yang sudah lanjut usia.

Rangkaian amalan-amalan yang telah ditetapkan oleh masingmasing tarekat itu dilaksanakan oleh para pengikutnya untuk mencapai maqām atau tingkat tertentu di bawah bimbingan guru tarekat yang disebut murshid atau khalifah. Posisi murshid dalam suatu tarekat memiliki tempat yang sangat penting untuk sampainya seorang murid kepada Tuhan. Orang yang mengikuti tarekat tanpa bimbingan guru maka berakibat jatuh kepada kekafiran atau kefasikan. ${ }^{14}$ Tingkatan-tingkatan (maqāmät) dimaksud, misalnya zuhd, wara', sabar, tawä ${ }^{\prime}$ ', takwa, ridā, mahabbah dan makrifat, tetapi nama dan tertib urutan maqāmāt itu tidak sama antara satu aliran tarekat dengan aliran tarekat lainnya. Ada satu kesamaan umum yang disetujui oleh aliranaliran tarekat mu'tabarah bahwa semua maqam tersebut dapat dibagi kepada empat tingkat, yaitu syariat, tarekat, hakikat dan makrifat.

Pada maqam syariat, seseorang harus memahami dan melaksanakan hukum syariat yang mencakup iman, Islam dan ihsan. Tingkatan selanjutnya adalah maqäm tarekat di mana seseorang harus melaksanakan rangkaian amalan-amalan atau latihan di bawah bimbingan seorang murshid. Pada level selanjutnya adalah maqām hakikat di mana seseorang lebih menyempurnakan iman dan keyakinannya kepada Allah dengan melakukan latihan-latihan. Akhirnya, sampai ke maqām tertinggi yang disebut makrifat. Pada maqām makrifat ini, seseorang telah mengenal Allah dengan pengenalan yang sesungguhnya dalam bentuk haqq al-yaqin atau 'ayn alyaqin. Setelah itu seseorang akan sampai kepada fana $\bar{a}^{-15}$ dan $b a q \bar{a}^{, 16} .{ }^{16}$ Salah satu amalan penting dalam tarekat Naqshabandīyah ${ }^{17}$ ketika

14 'Abd al-Raḥmān b. Muhammad Dimashqīyah, Haqāiq Khatīrah al-Ṭariqah alNaqshabandìyah (Riyāḍ: Dār al-Muslim, 1998), 22.

${ }^{15}$ Ketika fana $\vec{a}$, seluruh perhatian terpusat ke alam batin hingga kesadaran terhadap alam luar menjadi senyap yang biasa disebut juga dengan ecstasy. Lihat Simuh, Sufisme Jawa: Transformasi Tasawuf Islam ke Mistik Jawa (Jakarta: Narasi, 2016), 50.

${ }^{16}$ Latief, Gerakan Kaum Tua di Minangkabau, 112.

17 Menurut Dobbin, Tarekat Naqshabandīyah lebih awal masuk ke Minangkabau dibandingkan Tarekat Shattarīyah. Tarekat Naqshabandīyah lebih popular di daerah Lima Puluh Kota dan Tanah Datar. Lihat Dobbin, Kebangkitan Islam dalam Ekonomi Petani, 146. Berbeda halnya menurut Yerri S. Putra, bahwa berdasarkan bukti-bukti yang ada, Tarekat Shattarìyah lebih dahulu 127 tahun berkembang di Minangkabau dibandingkan dengan Tarekat Naqshabandīyah. Hal ini dapat dilihat dari penetapan awal dan akhir Ramadan di sekitar Pariman dan Padang Panjang. Penganut Tarekat Shațarīyah terlambat melaksanakan puasa atau mengakhiri puasa Ramadan dua hari 
sulük adalah räbitah yang dilakukan dengan cara ber-khalwab. ${ }^{18}$ Sulük dilakukan selama 40 hari, 20 hari atau 10 hari untuk mencapai puncak tertinggi.

\section{Kayfìyāt Rābitah di Minangkabau}

Ada beberapa rangkaian kegiatan sulük yang dilakukan dalam tarekat Naqshabandīyah ${ }^{19}$ yaitu tala'i dhikr atau bay'at al-dbikr, räbitab dan dhikr khafi atau dhiker qalb. Tala'i dhiker atau bay'at al-dhiker adalah adanya pengakuan pimpinan tarekat untuk menerima seseorang untuk mengikuti sulük dan bimbingan guru kepada murid yang berkaitan dengan zikir dan cara-caranyanya. Permohonan murid kepada guru untuk mengikuti sulük ini popular dengan istilah "mengambil kaji" (pelajaran).

Teknis mengambil kaji kepada guru dengan bersimpuh di hadapan guru, kemudian guru akan menunjukkan kepada murid letak hati sanubari dan memberikan nasihat-nasihat yang disebut tawajjuh. Ketika guju menunjukkan letak hati, ia membaca istighfär sebanyak 25 kali yang diikuti oleh murid. Selanjutnya membaca surah al-Fātiḥah satu kali serta membaca surah al-Ikhlāṣ tiga kali dengan niat bahwa semua pahala bacaan tadi dihadiahkan untuk Nabi Muhammad, keluarga dan sahabatnya dan imam-imam dalam tarekat Naqshabandīyah. Ini dilakukan dengan cara memejamkan mata dengan penuh konsentrasi. Ketika guru memberikan nasihat-nasihat kepada muridnya, semua pintu harus dikunci hingga orang lain tidak

setelah kelompok Tarekat Naqshabandīyah melakukannya, hingga kelompok Tarekat Shațarìyah disebut "orang yang puasa kemudian" sedangkan kelompok Tarekat Naqshabandiyah disebut "orang yang puasa dahulu". Lihat Yerri S. Putra, Minangkabau di Persimpangan Generasi (Jakarta: Insist Press, 2007), 426; Bandingkan Fathurahman, Tarekat Syattariyah di Minangkabau, 46. Menurut A. A. Navis, tumbuh suburnya ajaran tarekat di Minangkabau tidak lepas dari campur tangan penguasa pada waktu itu. Lihat A.A. Navis, Alam Terkembang Jadi Guru Adat dan Kebudayaan Minangkabau (Jakarta: Temprint, 1986), 28.

18 Ketentuan lain yang diatur ketika melakukan sulük di surau oleh guru adalah terlarangnya murid memakan daging, kecuali sedikit setelah menjalani sulük selama 20 hari, kemudian menghentikannya sampai ibadah sulük selesai. Selain itu, orang yang sulük tidak dibenarkan bergaul dengan istri atau suaminya. Makan minum dan tidur diatur dengan jumlah yang sesedikit mungkin. Waktu dan pikiran diarahkan berzikir sebanyak-banyaknya di samping melakukan ibadah-ibadah wajib lainnya seperti salat lima waktu atau puasa di bulan Ramadan. Lihat Latif, Gerakan Kaum Tua di Minagkabau, 108.

${ }^{19}$ Ibid., 83. 
mengetahui apa yang dilakukan murid dan guru tarekat. ${ }^{20}$ Setelah itu, baru diajarkan macam-macam zikir berdasarkan kemampuan murid.

Sedangkan räbitah adalah membayangkan wajah guru yang mengajar zikir itu dalam pikiran. ${ }^{21}$ Ini dilakukan setiap melakukan zikir untuk menghilangkan perasaan was-was (keraguan) yang dapat mengganggu kosentrasi ketika berzikir dan untuk menambah ketekunan dalam beribadah serta mempercepat "sampainya" murid kepada Allah. Seorang murid membayangkan kehadiran guru seraya meyakini bahwa keberadaan shaykh-nya itu sama dengan keberadaan Nabi. Hal ini karena pada dasarnya shaykh adalah pengganti Nabi. ${ }^{22}$

Dhike khäfi atau dhiker qalbi yaitu mengingat Allah dalam hati tanpa diucapkan dengan lidah dan tanpa suara. Dhikr khäfi ini memiliki tingkatan-tingkatan yang harus dilalui murid. Keberhasilan murid dalam melalui masing-masing tingkatan tergantung dari penilain guru. Jika guru melihat seorang murid sudah sempurna dalam melakukan zikir, maka murid boleh pindah pada tahap selanjutnya. Tingkatantingkatan zikir itu ada lima, yaitu dhiker ism al-dhät, dhiker latä̀̈if, dhiker nafy wa ithbät, dhiker wukeüf dan dhiker muqärabah.

Zikir ism al-dhät adalah mengingat Allah dalam hati dengan menyebut kata "Allah" yang jumlahnya paling sedikit 7000 kali dalam sehari semalam. Zikr lata' if adalah zikir yang dipusatkan pada bagianbagian tertentu dalam tubuh yang masing-masingnya disebut latifah, yaitu bagian halus yang dianggap sebagai pusat peredaran darah dan mempunyai fungsi sangat vital di dalam tubuh manusia yang meliputi jantung, paru-paru, hati, limpa, empedu, otak, dan seluruh badan. Adapan lafal zikirnya sama dengan di atas yaitu kata "Allah" yang hanya diingat di dalam hati tanpa suara dan jumlahnya 11.000 kali dengan perincian sebagai berikut:

a. Untuk latifah qalb yang berpusat di jantung dibaca 5.000 kali.

b. Untuk latifah rüb yang berpusat di paru-paru dibaca 1.000 kali.

c. Untuk latïfah sirr yang berpusat di hati dibaca 1.000 kali.

\footnotetext{
20 Surau dengan berbagai kelengkapan untuk melakukan sulük dapat dijumpai di Batuhampar Payakumbuh yang didirikan oleh Shaykh Abdurrahman (1777-1888) yang memiliki hampir 30 bagunan yang terdiri dari bagunan utama, bangunan untuk menyambut tamu, surau-surau kecil untuk murid dan bangunan khusus untuk sulük. Lihat Azyumardi Azra, Pendidikan Islam: Tradisi dan Modernisasi di Tengah Tantangan Milenium III (Jakarta: Kencana, 2012), 154.

${ }^{21}$ Lihat Dimashqīyah, Haqä’iq Khatìrah al-Tariqah al-Naqshabandìyah, 123.

${ }^{22}$ Fathurahman, Tarekat Syattariyah di Minangkabau, 55-56.
} 
d. Untuk latîfah khäfí yang berpusat di limpa dibaca 1.000 kali.

e. Untuk latîfah akhfä yang berpusat di empedu dibaca 1.000 kali.

f. Untuk latifah nafs yang berpusat diotak dibaca 1.000 kali.

g. Zikir untuk seluruh badan (kullu jasad) dibaca 1.000 kali.

Sedangkan dbikr nafy wa ithbät yaitu mengingat di dalam hati kalimat "lā ilāha illā Allāh". Dinamakan dhiker nafy wa ithbät karena bagian awal kalimat tersebut, yaitu "lā ilāha" bermakna meniadakan semua yang berhak dijadikan tuhan. Sedangkan kalimat "illā Allāh" berarti menetapkan bahwa hanya Allah saja yang wajib disembah dan ditaati. Dalam melakukan zikir diatur dengan cara memejamkan mata dan mengatupkan mulut, gigi atas merapat ke gigi bawah, lidah lengket ke langit-langit, nafas ditahan lalu mulai berzikir di hati dengan membaca kalimat "lā ilāha" dengan tarikan nafas di bawah pusat lalu diteruskan ke atas sampai ke otak dan ke bahu kanan. Kemudian dilanjutkan dengan kalimat "illā Allāh" yang disertai dengan hempasan nafas ke hati sanubari sehingga panas seluruh badan. Ketika sampai di hati sebelah kiri lalu diucapkan kalimat "Muhammad Rasūl Allāh". Bacaan ini diulang sekuat nafas serta menghadirkan arti kalimat tersebut dalam pikiran. Zikir ini dimaksudkan agar orang yang mengamalkannya selalu mengingat kematian.

Adapun dhikr wuqüf adalah zikir dengan membaca kalimat "lā ilāh illā Allāh" juga tanpa suara dimaksudkan untuk lebih memantapkan hati dalam beribadah dan meyakinkah seakan Allah senantiasa berdiri dihadapannya dan Allah senantiasa mengetahui apa yang diperbuatnya. Dengan demikian hati dan pikirannya tidak akan pernah lengah dari tujuan utamanya yaitu beribadah kepada Allah.

Dhiker muqārabah juga dengan mengucapkan kalimat "lā ilāh illā Allāh" di dalam hati berulang kali. Ini dilakukan untuk lebih memantapkan keyakinan berzikir bahwa walaupun ia tidak dapat melihat Allah (dengan matanya) ketika ia sedang beribadah, namun Allah tetap melihatnya. Jika ia tidak dapat melihat Allah, padahal ia ingin sekali melihat Allah, maka ia seakan-akan selalu mengintip dan mengintai datangnya saat melihat Allah. Dalil yang digunakan tentang melihat Allah ini yaitu "fa in lam takun tarāh fainnah yarāk".

Dhikr muqārabah ini dibagi menjadi beberapa bentuk, pertama, dhikr ahadiyat al-af'äl, yaitu zikir yang dilakukan untuk memperkuat keyakinan tentang keesaan Allah dalam bentuk perbuatan-Nya. Perbuatan Allah merupakan perbuatan hakikat, sedangkan perbuatan 
manusia dapat terjadi karena adanya perbuatan Allah dan atas kehendak-Nya. ${ }^{23}$ Oleh karena itu, lafal "lā ilāha illā Allāh" yang dibaca tersebut harus dipahami dengan "lā fā'il illā Allāh" (tidak ada yang dapat berbuat kecuali Allah). Kedua, dhiker muqärabat al-ma ‘yyah yang bertujuan untuk memperbuat keyakinan bahwa Allah selalu bersama kita. Maka lafal "lā ilāh illā Allāh" yang diucapkan harus diartikan "lā mawjūda illā Allāh" (tidak ada satupun yang benar-benar ada, kecuali Allah). Ketiga, dhiker muqärabät al-aqrabiyah. Zikir ini bertujuan untuk memantapkan keyakinan bahwa Allah selalu dekat dengan kita dan selalu melindungi kita. Maka lafal "lā ilāh illā Allāh" harus diartikan dengan "lā maqșūda illā Allāh" (tidak satupun yang dituju, kecuali Allah semata). Keempat, dhiker muqārabat al-dhät. Zikir ini dilakukan untuk memperkuat keyakinan tentang kemahaesaan Allah. Maka kalimat "lā ilāh illā Allāh" harus dimaknai dengan "lā ma'būda illā Allāh" (tidak ada yang boleh disembah, kecuali Allah semata). Kelima, dhiker muqärabat hubb al-shirf. Zikir yang dilakukan bertujuan untuk memperkokoh keyakinan bahwa Allah sangat sayang kepada hambaNya sebagaimana kita juga sayang kepada-Nya. Lafal "lā ilāh illā Allāh" yang dilantunkan dalam zikir ini harus dimaknai "lā maḥbūb illā Allāh" (tidak satupun yang dikasihi, kecuali Allah).

Bagi orang yang melakukan sulukk, zikir-zikir itu dilakukan secara bertahap. Apabila seorang murid telah selesai melakukan rangkaian zikir tersebut, maka dia harus mengulanginya lagi seperti semula sampai masa sulūknya berakhir di hari yang keempat puluh.

\section{Kritik Abdul Karim Amrullah terhadap Rābitah dalam Tafsir al- Burhān}

Tafsir al-Burbān termasuk tafsir tertua yang ada di Indonesia. Usaha menerjemahkan dan menafsirkan al-Qur'ān ke dalam Bahasa Indonesia atau bahasa daerah menurut Tim Departemen Agama dimulai pada tahun 1928, yaitu ketika ditulisnya al-Furqān fì Tafsìr alQur'an karya A. Hassan Bandung. Selanjutnya diikuti oleh Qur'an Indonesia yang ditulis oleh Syarikat Kwekschool Muhammadiyah bagian karang mengarang yang dicetak tahun 1932, Tafsir Hibarna karya Iskandar Idris yang dicetak tahun 1934, Tafsir al-Qur'an Karim karya A. Halim Hassan, Zainal Arifin Abbas dan Abdurrahman Haitami yang dicetak tahun 1938, Tafsir Qur'an Karim karya Mahmoed Joenoes yang dicetak tahun 1938, Tafsir Qur'an Bahasa Indonesia karya Mahmud Aziz

${ }^{23}$ Latief, Gerakan Kaum Tua di Minangkabau, 112. 
yang dicetak tahun 1942, Tafsir Qur'an karya Zainuddin Hamidy Cs yang dicetak tahun 1963, Tafsir Sinar Karya Malik Ahmad (tanpa tahun), Tafsir al-Azhar karya Hamka yang dicetak tahun 1966, Tafsir alSyamsiyah karya K.H. Sanusi yang diterbitkan sekitar tahun 1935, Tafsir al-Bayan karya M. Hasbi Ash-Shidieqy yang diterbitkan tahun 1971, Tafsir al-Qur'an Madjied "An Nur" karya Hasbi ash-Shiddieqy yang diterbitkan tahun 1973, Al-Qur'an dan Terjemahannya oleh redaksi Penerbit Bahrul 'Ulum Pimpinan H. Bakhtiar Surin (tanpa tahun), AlQur'an Bacaan Mulia karya H.B Jassin tahun yang diterbitkan tahun 1977, Al-Qur'an dan Terjemahannya oleh Yayasan Penyelenggara dan Penterjemahan al-Qur'an Departemen Agama RI yang diterbitkan tahun 1967, dan Tafsir al-Qur'an, oleh Dewan Penafsir al-Qur'an Departemen Agama RI (tanpa tahun). ${ }^{24}$

Dalam konteks kajian ketarekatan, bagi Abdul Karim Amrullah, eksistensi tarekat bukanlah suatu hal yang baru. Ia telah mengenal tarekat semenjak usia belia, mengingat ayahnya sendiri, Amrullah, adalah pimpinan tarekat Naqshabandiyah ${ }^{25}$ [tarekat yang dikembangkan oleh Bahā' al-Dīn al-Naqshābandī (717-791 H/1317$1389 \mathrm{M})$ ] dengan berbagai amalan tarekat yang dilakukan penganutnya di daerah Bayur Maninjau, Sumatera Barat.

Abdul Karim Amrullah mengkritik räbitah yang dilakukan oleh kelompok tarekat Naqshabandīyah yang tersebar di Minangkabau. Mekanisme meminta pertolongan melalui räbitah adalah dengan cara menghadirkan wajah guru (membayangkan wajah guru) ${ }^{26}$ ketika zikir

\footnotetext{
${ }^{24}$ Ichsan, dkk., Muqaddimah, 73.

25 Hamka, Ayabku, 43. Lihat juga, Tamrin Kamal, Purifikasi Ajaran Islam pada Masyarakat Minangkabau: Konsep Pembaruan H. Abd. Karim Amrullah Awal Abad Ke-20 (Padang: Angkasa Raya, 2005), 115.

${ }^{26}$ Menghadirkan wajah guru ketika sulük dapat dilakukan dalam beberapa bentuk yaitu: pertama, menghadirkan wajah guru di depan mata secara sempurna. Kedua, membayangkannya dari kiri ke kanan dengan memusatkan perhatian kepada rohaniahnya sampai terjadi sesuatu yang gaib. Apabila rohaniah murshid yang dijadikan räbitah itu lenyap, maka murid dapat menghadapi peristiwa yang terjadi, tapi jika peristiwa itu lenyap, maka murid harus berhubungan kembali dengan rohaniah guru sampai peristiwa yang sama terulang kembali. Itu dilakukan secara berulang-ulang sampai fanä' hingga menyaksikan peristiwa gaib tanda kebesaran Allah. Ketiga, mengkhayalkan rupa guru di tengah-tengah dahi. Keempat, menghadirkan rupa guru di tengah-tengah hati. Kelima, mengkhayalkan rupa guru di kening kemudian menurunkannya ke hati. Keenam, menafikan (meniadakan) dirinya dan menetapkan keberadaan guru. Cara ini lebih kuat untuk menangkis aneka ragam
} 
agar räbitah itu menyampaikan kepada Tuhan apa yang diharapkan murid dan untuk menghilangkan was-was ketika melakukan sulük. ${ }^{27}$ Perbuatan yang seperti ini menurut Abdul Karim Amrullah tidak pernah diajarkan oleh Nabi Muhammad. Berdoa melalui räbitah dilarang Allah sebagaimana yang terdapat dalam surah al-Bayyinah ayat 6:

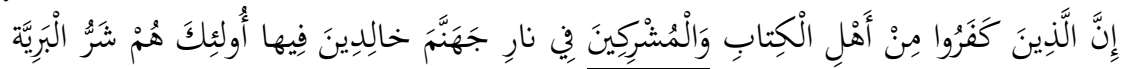

Menurut Abdul Karim Amrullah, menggunakan perantara atau räbitah untuk menyampaikan maksud tertentu kepada Allah termasuk perbuatan syirik yang dilarang Allah sebagaimana yang terdapat dalam ungkapan kata "al-mushrikīn" pada ayat 6 surah al-Bayyinah di atas. Syirik yang dimaksud adalah syirik dalam bentuk sifat Allah. Orang yang meyakini bahwa ada kekuasaan lain-seperti menjadikan, menghidupkan, mematikan, menyakitkan dan menyenangkan-yang memberikan efek selain Allah dipandang sebagai pelaku perbuatan syirik (mushrik). Orang yang memperserikatkan Tuhan dalam bentuk sifat ini menyebabkan orang tersebut menjadi $\mathrm{kafir}^{29}$, meskipun orang yang melakukan syirik itu tetap melakukan salat, puasa, zakat dan ibadah lainnya.

Pandangan Abdul Karim Amrullah menyamakan orang yang melakukan räbitah dengan pelaku perbuatan syirik, karena menyamakan sifat Allah dengan sifat makhluk yang mampu menyampaikan keinginan seseorang dalam melakukan sesuatu. Menghadirkan wajah guru ketika sulük untuk sampai kepada sesuatu yang diharapkan artinya sama dengan memposisikan guru seperti Tuhan, padahal Allah adalah Zat Yang Maha Esa. Kemahaesaan Allah dapat dalam bentuk zat-Nya, sifat-Nya, perbuatan-Nya dan hak-Nya. Tidak seorangpun berhak menetapkan hukum shar i $>$ selain Allah, meskipun ia seorang nabi atau rasul. Keesaan Allah ditegaskan oleh alQur'ān dalam surah al-Ikhlāṣ..$^{30}$ Menurut Sulaiman al-Rasuli dalam kitab tafsirnya al-Qawl al-Bayān bahwa ungkapan Esa semakna dengan pemahaman yang dikemukan oleh Abdul Karim Amrullah. Esa

ujian dan gangguan-gangguan. Lihat A. Fuad Said, Hakikat Tarekat Naqshabandiyah (Jakarta: PT. Al-Husna Zikra, 1996), 71-72.

27 Amrullah, al-Burhān, 132.

${ }^{29}$ Ibid., 131.

${ }^{30}$ Ibid., 333. 
menurut Sulaiman al-Rasuli adalah bahwa Allah itu tunggal atau sendiri. $^{31}$ Atas dasar inilah Abdul Karim Amrullah mengafirkan golongan tarekat yang melakukan räbitah dengan memposisikan makhluk di posisi Khäliq yang disebut syirik sifat bagi Allah. ${ }^{32}$

Berkaitan dengan persoalan räbitah ini, Abdul Karim Amrullah telah melakukan kritik kepada golongan tarekat ketika terjadi perdebatan antar ulama di Bukit Surungan, Padang Panjang pada tahun $1905^{33}$ dan di Padang pada tahun $1906 . .^{34}$ Dalam perdebatan tersebut, penganut tarekat Naqshabandīyah kewalahan menghadapi argumentasi yang dikemukakan para "golongan muda". ${ }^{35}$ Polemik tarekat dari pertemuan ulama di Padang ini kemudian berujung kepada usaha yang dilakukan oleh Abdullah Ahmad dengan cara menulis surat kepada Ahmad Khatib al-Minangkabawi ${ }^{36}$ yang mempertanyakan seputar tarekat yang berlaku di Minangkabau. ${ }^{37}$

31 Sulaiman al-Rasuli al-Khalidi, Qawl al-Bayān (Fort De Kock: al-Matbaah alIslamiyah, 1929), 122.

32 Abdul Karim Amrullah, 'Umdah al-Anām fi Tlm al-Kalām (Padang: al-Munir, 1916), 17.

33 Latief, Gerakan Kaum Tua di Minangkabau, 510. Perdebatan tentang persoalan tarekat mengemuka di Minangkabau terjadi empat kali. Salah satu persoalan yang diperdebatkan adalah persoalan räbitah. Tema yang diangkat tentang tarekat yang pertama kali dilakukan di masjid Sianok, Bukittinggi tahun 1903 yang dihadiri oleh beberapa orang ulama dari daerah Agam. Kedua, di Bukit Sarungan, Padang Panjang tahun 1905. Pertemuan ini dihadiri oleh ulama dalam jumlah yang lebih besar yang dihadiri oleh ulama kaum muda seperti Haji Abdullah Ahmad, Shaykh Djamil Djambek dan Haji Abdul Latif, di samping Shaykh Abdul Karim Amrullah Sendiri. Sedangkan dari kaum tua, dihadiri oleh Shaykh Khatib Ali, Shaykh Bayang dan Shaykh Abbas Qadhi. Ketiga, pertemuan pada tahun 1905 yang diadakan di Jembatan Besi, Padang Panjang. Keempat, pertemuan yang dilakukan pada tahun 1906 yang diadakan di kota Padang. Ibid., 390.

${ }^{34}$ Hamka, Ayabku, 291.

35 Akhria Nazwar, Ahmad Khatib al-Minangkabawi Ilmuan Islam di Permulaan Abad Ini (Jakarta: Pustaka Panji Mas, 1983), 41.

36 Shaykh Ahmad Khatib al-Minangkabawi dilahirkan di Koto Gadang, Bukittinggi tanggal 26 Mei $1860 \mathrm{M}$ dan wafat di Mekah pada tanggal 14 Maret 1916. Ia wafat dalam usia 56 tahun. Pada tahun 1879 ia menikah dengan seorang gadis bangsawan Arab yang bernama Khadijah. Khadijah merupakan anak dari Shaykh Shaliah Kurdi sampai Ahmad Khatib diijinkan oleh Sharif Mekah untuk mengajar di Masjidil Haram yang merupakan pusat pendidikan pada masa itu. Lihat Hamka, Ayabku, 271-272. Lihat juga, Nazwar, Abmad Khatib al-Minangkabawi, 11-15.

37 Pertanyaan yang diajukan Abdullah Ahmad kepada Ahmad Khatib alMinangkabawi adalah: pertama, Tarekat Naqshabandīyah-Khalidiyah apakah memiliki sumber dari dari syariat atau tidak? Kedua, apakah silsilah tarekat itu sampai kepada Rasul atau tidak? Ketiga, meninggalkan makan daging ketika sulük apakah 
Jawaban yang diberikan Ahmad Khatib dalam bukunya Iz̧hār Zagl Kädbibin fi Tashabbubibim pada tahun 1324 H/1906 M, ternyata bersesuaian dengan pendapat yang dikemukakan oleh Abdul Karim Amrullah bahwa räbitah itu merupakan perbuatan bid'ah. ${ }^{38}$ Artinya, persoalan tarekat yang ada di Minangkabau telah dikritik oleh Abdul Karim Amrullah sebelum keluarnya tulisan Ahmad Khatib alMinangkabawi, meskipun karya Abdul Karim Amrullah tentang räbitah terlambat dipublikasikan kepada masyarakat. Karya Abdul Karim Amrullah muncul setelah adanya pembelaan Shaykh Mungka pada tahun $1906 \mathrm{M}$ tentang perlunya tawassul dalam tarekat Naqshabandìyah.

Menurut Ahmad Khatib, ada persamaan antara menyembah berhala dengan orang yang melakukan räbitah. Perbedaannya adalah bahwa patung itu dibuat oleh tangan manusia, sedangkan guru-guru itu dikhayalkan oleh hati manusia. Namun keduanya itu telah

berasal dari Rasul atau tidak? Keempat, Suluke 40 hari, 20 hari, atau 10 hari apakah memiliki dasar dari syariat atau tidak? Kelima, melakukan rābitah apakah memiliki dasar dalam syariat atau tidak? Lihat Latief, Gerakan Kaum Tua di Minangkabau, 449.

38 Berikut jawaban yang diberikan Ahmad Khatib berkaitan dengan persoalan tarekat yang diajukan oleh Shaykh Abdullah Ahmad: pertama, Tarekat Naqshabandīyah yang berkembang di Minangkabau hanyalah dapat dikatakan sesuai dengan tarekat Nabi dan para sahabat serta para awliy $\bar{a}$-Nya, bila ia menganjurkan kepada penganutnya untuk mempelajari dan mengamalkan ajaran agama yang terdapat dalam al-Qur'ān dan Sunnah yang telah diuraikan dalam ilmu tauhid, fiqh dan tasawuf. Jika tidak demikian, maka perbuatan itu adalah bidah yang tidak ada asalnya dalam syariat. Bahkan termasuk larangan Allah dan Rasul-Nya serta para awliy $\vec{a}$. Kedua, amalan yang silsilahnya sampai kepada Rasul hanyalah talqin-zikir perorangan dan talqin zikir bersama. Tetapi zikir-zikir dan segala macam kayfiyat-nya seperti yang biasa dilakukan penganut Tarekat Naqshabandìyah di Minangkabau, misalnya dhiker ism al-dhät adalah bid'ah. Perbuatan itu hanya diada-adakan saja oleh beberapa pemimpin tarekat tersebut. Silsilahnya tidak sampai kepada Rasul. Ketiga, meninggalkan makan daging selama melakukan sulük juga tidak ada dasarnya dalam shar', bahkan bertentangan dengan ayat al-Qur'ān dan hadīth-ḥadìth yang berkaitan dengan persoalan makanan. Keempat, sulük yang dilakukan selama 40 hari, 20 hari atau 10 hari, tidak pernah dilakukan Nabi dan para sahabatnya. Ini dapat dipastikan karena kitab fiqh, hadis dan tasawuf tidak pernah menyebut masalah ini. Padahal, para ahli hadis sangat teliti dan rajin sekali mencatat setiap perkataan, perbuatan dan taqrir Nabi dan para mujtahid yang datang kemudian menguraikannya dalam kitabkitab mereka. Lima, räbitah yang dipakai dalam Tarekat Naqshabandìyah sebagai wasilah dalam berzikir juga tidak ada dasarnya dari shar: Itu hanya bidah dalam agama. Pengertian yang zăhir dalam ayat-ayat dan hadīth- hạaīth bahkan melarangnya. Ibid., 408-409. 
dijadikannya sebagai wasilah untuk sampai kepada Allah dengan cara kbudū' dan tadarru' (merendahkan diri). ${ }^{39}$ Räbitah yang dipraktikkan dalam Tarekat Naqshabandīyah sebagai wasilah dalam berzikir juga tidak ada dasarnya dalam shar'. Itu adalah bid'ah agama. Pengertian yang zahir pada ayat-ayat al-Qur'ān dan beberapa hadīth Nabi Muhammad menegaskan bahwa räbitah tidak memiliki dasar dalam naș bahkan terlarang melakukannya.

Ke-bid'ah-an melakukan räbitah menurut Abdul Karim Amrullah karena perbuatan tersebut termasuk bid'ah ibadah atau bid'ab shari. Artinya, bid'ah yang dilakukan golongan tarekat tercakup dalam perbuatan ibadah, ${ }^{40}$ sedangkan disebut bid'ah shar' $i$ karena perbuatan bid'ab itu tidak memiliki dalil dari al-Qur'ān atau hadìth tentang boleh atau tidaknya melakukan perbuatan tersebut. Tidak termasuk bid'ah shar $\bar{i}$ menurut Abdul Karim Amrullah berkaitan dengan alat-alat modern yang berkembang sekarang, bahkan agama mendorong untuk menemukannya ${ }^{41}$ seperti penemuan alat-alat teknologi yang berhasil diciptakan manusia untuk kemaslahatan manusia. ${ }^{42}$ Orang-orang yang melakukan perbuatan bid'ah, maka si pelaku akan tertolak untuk masuk ke dalam Telaga al-Kawthar yang terdapat dalam surga, selama bid'ah yang dilakukannya itu tidak sampai kepada kekafiran atau murtad. ${ }^{43}$ Penafsiran ini disampaikan Abdul Karim Amrullah ketika menafsirkan ayat pertama surah al-Kawthar.

Menurut Abdul Karim Amrullah, perbuatan bid'ah yang dilakukan golongan tarekat dalam bentuk räbitab termasuk perbuatan munkar karena menyalahi Sunnah Nabi. Selanjutnya, Abdul Karim Amrullah menegaskan perbuatan bid'ah lain di samping räbitah dalam tarekat seperti melakukan khalwat ketika subük dengan melakukan zikir

\footnotetext{
${ }^{39}$ Ibid., 449.

40 Abdul Karim Amrullah membagi bidah dilihat dari segi cakupannya kepada bidah iktikad dan bidah ibadah. Lihat Abdul Karim Amrullah, Pedoman Guru Pembetulkan Kiblat Paham Keliru (Fort de Kock: Drukerij Limbago, 1930), 136-137 dan 164-167.

${ }^{41}$ Ibid., 168.

42 Azra, kesalahan dari munculnya bid'ah dan khurafät dalam tasawuf yang dilakukan oleh masyarakat tentu tidak dapat dibebankan kepada para ahli tasawuf, karena para ahli tasawuf tidak mengajarkan kepasifan dan penarikan diri dari masyarakat, sebaliknya mereka mengimbau agar kaum muslimin bersifat aktif. Bagi ahli tasawuf, pemenuhan kewajiban duniawi kaum muslimin merupakan bagian integral dari kemajuan spiritual dalam perjalanan mistis. Lihat Azyumardi Azra, Jaringan Ulama Timur dan Kepulauan Nusantara Abad XVII dan XVIII (Jakarta: Kencana, 2007), 357. ${ }^{43}$ Amrullah, al-Burhān, 253.
} 
berpuluh-puluh hari, tidak mengkosumsi daging selama sulük $k^{44}$, tidak berhubungan intim dengan istri atau suami selama sulük, zikir dengan mengubah-ubah suara dan bacaan, dan lain-lain. ${ }^{45}$ Semuanya itu termasuk perbuatan yang tidak mempunyai dasar dari Rasulullah.

Kritik yang dikemukakan oleh Abdul Karim Amrullah, sebagai kaum muda, tentang räbitah kemudian menjadikannya "alien". Karena hal inilah ia mendapatkan panggilan, dari kaum tua, dengan istilahistilah yang terkesan merendahkan dirinya serta ulama yang sependapat dengannya. Panggilan-panggilan tersebut seperti malim baru, malim muda, faqih muda, firqah baru, firqah jadidah, kaum muda majdi dan kaum muda Wahabi. ${ }^{46}$

\section{Respons Abdul Karim Amrullah terhadap Argumen Golongan Tua tentang Räbitah}

Di antara ulama tarekat yang mencoba mempertahankan sulük dipelopori oleh Shaykh Mungka (1857-1921 M) sebagai wakil dari golongan tua dengan menulis buku yang berjudul Irghäm al-Nufil Muta'annitin fì Inkāribim Räbitah al-Wäsilin. Dari tulisan Shaykh Mungka ini kemudian Abdul Karim Amrullah juga memberikan tanggapannya dengan menulis buku yang berjudul Qäthíu Riqäb alMulhidin yang selesai ditulis pada tahun 1910. Sebelum terbitnya buku Qäthi' Riqāb al-Mulhidìn yang menjelaskan tentang tarekat dan bantahan tentang tawassul, Abdul Karim Amrullah telah menyelesaikan penulisan buku lainnya yang juga membicarakan tentang tarekat, yaitu Ižbār Asạtìi al-Mudällìn fi Tashäbubibim bi al-Mubtadīn yang berisi tentang kecaman terhadap Tarekat Naqshabandīyah yang ditulis tahun 1907 dan buku al-Suyūf al-Qätíah fì Da'äwìy al-Kädhibah yang berisi jawaban dari pertanyaan-pertanyaan tentang persoalan tarekat yang juga ditulis pada tahun 1907.

Menurut Shaykh Mungka yang mencoba mempertahankan tawaswul ketika sulūk memiliki dasar dalam al-Qur'ān surah al-Mā’idah ayat 35:

\footnotetext{
44 Di samping dilarangnya anggota sulük untuk mengkosumsi daging, peserta sulük juga dilarang makan ikan, telur dan sebagainya. Larangan itu dimaksudkan agar hati bulat tertuju kepada Allah sebab memakan sesuatu yang bernyawa ketika sulük dapat menutup pintu hati, memberatkan tubuh untuk berzikir dan menguatkan nafsu. Lihat Said, Hakikat Tarekat Naqshabandìah, 157.

45 Amrullah, Pedoman Guru Pembetulkan Kiblat Paham keliru, 130.

${ }^{46}$ Latief, Gerakan Kaum Tua di Minangkabau, 458.
} 


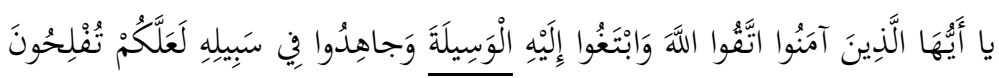

"Hai orang-orang yang beriman, bertakwalah kepada Allah dan carilah jalan yang mendekatkan diri kepada-Nya dan berjihadlah pada jalan-Nya supaya kamu mendapatkan keberuntungan".

Menurut Mungka yang dimaksud "wasīlah" dalam ayat tersebut mencakup apa saja yang dapat dijadikan jalan atau cara untuk melaksanakan taat kepada Allah. Wasilah juga dapat dilakukan dengan perantaraan para awliy $\vec{a}$ ' yaitu ulama yang dipandang telah mencapai martabat sebagai walìy Allāh. ${ }^{47}$

Menurut Abdul Karim Amrullah dalam bukunya Qạ̈ti‘ Riqäb alMulḩidin bahwa melakukan räbitah ketika sulük dengan cara membayangkan wajah guru merupakan perbuatan yang tidak berdasar dari al-Qur'ān dan hadīth. Tarekat yang benar menurut Abdul Karim Amrullah adalah tarekat yang dapat menyampaikan seseorang kepada Allah dengan cara mengikuti semua perintah Allah dan meninggalkan semua larangan-Nya. Selanjutnya tarekat itu dilakukan dengan ittiqād yang benar dengan semua sifat-sifat yang wajib bagi Allah dan RasulNya serta segala sifat-sifat yang mustahil bagi Allah dan Rasul-Nya. Kemudian menurutnya, bahwa tarekat yang benar adalah tarekat yang sesuai dengan tauhid, figh dan tasawuf. ${ }^{48}$

Maksud kalimat dalam surah al-Mā’idah ayat 35 "carilah kepadaNya al-wasilab" menurut Abdul Karim Amrullah bukan diartikan melakukan räbitah ketika sulük dengan cara membayangkan wajah guru untuk sampai kepada Allah. Tapi yang dimaksud dengan wasilah dalam ayat itu adalah mendekatkan diri kepada Allah dengan melakukan amal saleh dengan cara melakukan yang diperintahkan Allah dan meninggalkan yang dilarang-Nya. Mengetahui amal saleh dilakukan dengan cara menuntut ilmu yang dapat menyampaikan kepada Allah. ${ }^{49}$ Tarekat yang tidak sesuai dengan tauhid, fiqh dan tasawuf akan mengantarkan mereka kekal dalam neraka. Selanjutnya menurut Abdul Karim Amrullah membiarkan tersebarnya bid'ah sedangkan 'álim diam saja ketika tersebarnya bid'ah itu, maka perbuatan tersebut akan mengundang kemarahan Allah. ${ }^{50}$

\footnotetext{
${ }^{47}$ Ibid., 444.

48 Abdul Karim Amrullah, Qäti' Riqäb al-Mulhidin fì 'Aqä’id al-Mufsidīin (Padang: Drukerij Snaperes, 1916), 57-58.

${ }^{49}$ Ibid., 89.

${ }^{50}$ Ibid., 67.
} 
Syariat dan tasawuf merupakan dua ilmu yang saling berhubungan erat karena keduanya merupakan perwujudan dari kesadaran terhadap iman yang mendalam. Syariah merupakan perwujudan dari iman secara lahiriah sedangkan tasawuf mencerminkan perwujudan iman dalam aspek batiniah. Aspek lahir dan aspek batin merupakan satu kesatuan yang tidak dapat dipisahkan antara satu dengan lainnya.

Menurut Abdul Karim Amrullah seorang sufi yang telah melaksanakan tujuan-tujuan tasawuf, maka sebenarnya ia telah mengikuti Sunnah, namun orang yang tidak menginginkan pakaian yang bagus, memisahkan diri dari orang lain, tidak menginginkan makanan lezat, menolak ini dan itu untuk dirinya dan hanya berserah diri dengan cara mengulang-ulang zikir, atau tidak ingin meningkatkan ilmu pengetahuan yang dibutuhkan untuk meningkatkan kedudukan kaum muslimin, maka perbuatan seperti ini merupakan perbuatan yang menyesatkan. ${ }^{51}$

Penafsiran surah al-Mā’idah ayat 35 yang dijelaskan Abdul Karim Amrullah juga senada dengan pendapat Mahmud Yunus bahwa wasilah diartikan dengan jalan keridaan Allah. Sedangkan bentuk jalan keridaan Allah itu tidak dapat diketahui kecuali melalui penjelasan dari Allah itu sendiri yaitu dengan ilmu pengetahun, teguh dalam keimanan dan melakukan amal saleh. Secara substansi, arti wasilah menurut Mahmud Yunus adalah melakukan semua perintah-Nya dan meninggalkan semua larangn-Nya. Berpengetahuan saja tapi tidak diikuti dengan amal perbuatan, maka ilmu itu tidak akan menyampaikan seseorang kepada Allah. ${ }^{52}$

Penafsiran yang sama juga dikemukan oleh Hamka, bahwa yang dimaksud dengan wasilah adalah melakukan perbuatan baik dan berdoa yang dilakukan sendiri oleh pelaku. $W$ asilah juga bisa dilakukan dengan cara meminta bantuan kepada orang lain yang masih hidup, bukan orang yang sudah meninggal. Meminta doa kepada orang yang sudah meninggal dapat dikategorikan kepada perbuatan syirik yang tidak dilakukan oleh para sahabat Nabi, baik ketika mereka masih hidup atau setelah wafat. ${ }^{53}$

${ }^{51}$ Murni Djamal, DR. H. Abdul Karim Amrullab: Pengarubnya dalam Gerakan Pembaruan Islam di Minangkabau pada Awal Abad ke-20, terj. Theresia Slamet (Jakarta: INIS, 2002), 35.

${ }^{52}$ Mahmud Yunus, Tafsir Qur'an Karim (Jakarta: Mahmudiah, 1957), 112-113.

${ }^{53}$ Menurut Hamka, wasilah diungkapkan al-Qur'ān sebanyak dua kali, pertama dalam surat al-Mā'idah ayat 35 dan surat al-Isrā’ ayat 57 . Kedua surat ini menjelaskan bahwa wasilah adalah usaha untuk mendekatkan diri kepada Allah dengan cara 
Atas dasar inilah kemudian tawassul dibagi dalam dua bentuk, yaitu tawassul mashrüìyah dan tawassul ghayr mashrü‘yah. Tawassul mashrü ‘̀yah adalah tawassul yang dilakukan dengan amal saleh sendiri dan bertawassul kepada orang-orang yang saleh yang masih hidup. ${ }^{54}$

Benturan persoalan tarekat yang melibatkan banyak ulama di Minangkabau menyebabakan terpecahnya ulama ke dalam dua kelompok besar, yaitu "golongan tua" 55 dan "golongan muda". Menurut Yerri S. Putra, konflik lokal dalam persoalan tarekat ini terjadi dipengaruhi juga oleh faktor perebutan kehormatan dan pengikut yang terancam dengan adanya kritik terhadap eksistensi tarekat di Minangkabau. ${ }^{56}$ Ulama lain yang sependapat dengan Abdul Karim Amrullah dari "golongan muda" tentang bid'ah-nya menggunakan räbitah atau tawassul adalah Thaher Jalaluddin (18691956 M), ${ }^{57}$ Abdullah Ahmad (wafat 1934 M), ${ }^{58}$ Djamil Djambek

memperbanyak ibadah dan berdoa langsung kepada Allah. Lihat Hamka, Tafsir alAz̧ar VI (Jakarta: Panji Masyarakat, 1982), 274.

54 Abdul Mun'im Musthofa Halimah, Jejak Amal-amal Kemurtadan (t.t.: t.tp., t.th.), 284-286.

55 Asal mula penggunaan istilah golongan tua dan golongan muda berdasarkan umur. Disebut golongan tua karena umur mereka lima puluh tahun ke atas sebagai golongan yang mempertahankan tarekat. sedangkan disebut golongan muda karena usia yang membatalkan tarekat berasal dari para pemuda yang masih muda dengan usia tiga puluh tahun ke bawah. Lihat Fathurahman, Tarekat Syattariyah di Minangkabau, 50.

56 Putra, Minangkabau di Persimpangan Generasi, 425.

57 Shaykh Thaher Jalaluddin merupakan guru kedua Abdul Karim Amrullah yang berasal dari Minangkabau setelah Ahmad Khatib al-Minangkabawi. Secara politik, Thaher cenderung mengikuti Jamāl al-Dīn al-Afghānī dan Muhammad 'Abduh. Ketika kembali ke Minangkabau, Thaher mendirikan majalah al-Imam dengan melibatkan Abdul Karim Amrullah sebagai wakil dalam majalah al-Imam tersebut. Lihat Hamka, Ayabku, 274. Shaykh Thaher juga ahli dalam ilmu falak. Hal ini tergambar dari karyanya yang berjudul "Fāty kīrān pada Menentukan waktu yang Lima dan Hal Kiblat dengan Logaritma". Tulisan ini didedikasikannya sebagai wujud dari kecintaannya terhadap masyarakat Melayu. Lihat Muhammad Tahir Jalaluddin Minangkabawi, Fäty kirän pada Menentukan Waktu yang Lima dan Hal Kiblat dengan Logaritma (Singapura: Kasar Perak, 1938), 1.

${ }^{58}$ Haji Abdullah Ahmad lahir di Padang Panjang pada tahun 1887. Ia berangkat ke Mekah bersama dengan Abdul Karim Amrullah dan Djamil Djambek untuk belajar kepada Ahmad Khatib al-Minangkabawi. Lihat Djamal, Dr. H. Abdul Karim Amrullah, 18. Menurut Hamka, Abdullah Ahmad bergerak di bidang pendidikan (seperti sekolah Adabiyah di Padang), pers (berdirinya surat kabar Islam seperti alMunì, al-Akbbār, al-Ittifāq wa Iftirāq dan majalah "Buka Mata"), serta rumah yatim dan orang miskin. Abdullah Ahmad termasuk sosok yang supel dan mudah bergaul. 
(wafat 1947 M), ${ }^{59}$ dan Zainuddin Labay el Yunusi (1890-1924 M). ${ }^{60}$ Sedangkan pembelaan dari golongan Tarekat Naqshabandīyah terhadap bid'ah-nya melakukan tarekat muncul dari berbagai daerah di Minangkabau. Selain Shaykh Mungka, ulama lain yang melakukan pembelaan adalah Khatib Ali $^{61}\left(1861-1936\right.$ M $^{62}$ dari Muaro Labuah,

Kerenggangan hubungan Abdullah Ahmad dengan Abdul Karim Amrullah terjadi sejak "bertemannya" Abdullah Ahmad dengan Belanda bahkan ia mendapatkan subsidi untuk pembangunan sekolah Adabiah dan menerima "guru ordonansi" yang merupakan politik pendidikan Belanda dalam memberangus pendidikan pribumi yang ditentang oleh Abdul Karim Amrullah. Lihat Hamka, Ayabku, 278.

${ }^{59}$ Muhammad Djamil Djambek lahir di kota Bukittinggi tahun 1860. Ia merupakan anak Datuak Malaka yang menjabat sebagai Kepala Nagari Suku Kurai Bukittinggi. Pada awalnya, ia belajar di Kweekschool untuk dipersiapkan menjadi guru, namun kemudian ia lebih tertarik menjadi parewa. Ketertarikannya kepada agama Islam muncul ketika ia berusia 22 tahun dan mulai belajar di Mekah dengan Shaykh Ahmad Khatib al-Minangkabawi. Di samping melakukan studi Islam, ia juga belajar praktik sihir dari seorang Maroko di kota Mekah. Diceritakan bahwa ia mempraktikkan sihir tidak lama setelah kembali dari Mekah, tetapi setelah itu, ia menjauhi sihir sama sekali sekitar tahun 1905. Djamal, Dr. H. Abdul Karim Amrullah, 19. Hamka lebih rinci ketika menggambarkan ke-parewa-an Djamil Djambek ketika muda. Parewa di Minangkabau dapat dapat disejajarkan dengan istilah preman dalam bahasa Indonesia. Parewa menjunjung tinggi persahabatan, saling membantu, mempunyai hubungan luas dengan berbagai nagari, menghormati perempuan, menjaga kehormatan suku dan nagari, menghormati ulama dan mereka biasanya ahli silat, meskipun mereka hidup dari judi dan bermain sabung ayam. Djambek muda juga pernah menggunakan candu hingga mampu membedakan antara candu dengan rokok dari jarak jauh. Ada dua hal yang cukup popular tentang profil Djamil Djambek, yaitu dari ke parewa-nya dan keahliannya dari ilmu falak. Terjadinya perubahan sikap Djambek muda setelah belajar dengan Shaykh Ahmad Khatib di Mekah dan setelah ayahnya wafat. Djamil Djambek wafat tahun 1947 dalam usia 80 tahun dan dimakamkan di depan suraunya sendiri yang terletak tidak jauh dari Jam Gadang. Lihat Hamka, Ayahku, 279.

60 Zainuddin Labay el Yunusi merupakan kakak dari Rahmah el Yunusi sebagai pelopor berdirinya sekolah Diniyah Putri Padang Panjang. Zainuddin Labay lahir tahun 1890 dan merupakan murid dari Abdul Karim Amrullah ketika mengajar di Jembatan Besi, Padang Panjang. Ia menempuh sekolah dasar di Governamen sampai kelas IV dan belajar agama kepada ayahnya sendiri, Muhammad Yunus Pandai Sikek. Kemudian ia belajar ke Shaykh Abbas Padang Japang, Payakumbuh. Di usia Zainuddin Labay yang masih muda, 26 tahun, ia telah mendirikan sekolah yang bernama Diniyah School dan berhasil menerbitkan majalah al-Akhbar sebagai pendukung majalah al-Munir yang terbit di Padang. Ia termasuk pengangum Muhammad Abduh dan Mustafa Kamil sebagai pemimpin Mesir. Ibid., 301-303.

${ }^{61}$ Khatib Ali termasuk tokoh tarekat di Minangkabau yang berhasil menulis buku untuk mempertahankan tarekat yang berjudul Kitab al-Burban. Ada beberapa hal penting yang dikemukan Khatib Ali untuk mempertahankan tarekat, pertama, tarekat 
Solok, Shaykh Bayang (1864-1923 M) ${ }^{63}$ dari Padang, dan Shaykh Sulaiman al-Rasuli (1871-1970 M) ${ }^{64}$ dari Ampek Angkek Agam.

Kritik yang dilontarkan Abdul Karim Amrullah sebagai golongan muda tentang tawassul dalam tarekat tidak banyak membawa pengaruh terhadap pimpinan tarekat di daerah-daerah yang ada di Minangkabau pada waktu itu. Alasan yang digunakan oleh pembela tarekat dari golongan tua adalah karena kaum muda dianggap telah berani mencela Tarekat Naqshabandīyah padahal mereka tidak mempunyai pengetahuan dan pengalaman apapun tentang tarekat ini. Golongan muda juga berani berijtihad padahal pengetahuan mereka tidak memadai untuk itu. ${ }^{65}$

Naqshabandīyah merupakan tarekat dengan pengetahun yang sudah kokoh dan tidak perlu dikeragui lagi. Ini dibuktikan Khatib Ali dengan mengemukan defenisi tarekat, tujuan yang hendak dicapai, manfaat tarekat, keutamaan tarekat, silsilah tarekat, hukumnya menurut syara', isi ajaran tarekat dan macam-macam nama tarekat. Semuanya ini dinamai "mabadi' yang sepuluh". Kedua, ia menjelaskan dalildalil yang digunakan ketika melakukan dhiker qalb (tanpa suara), dalil mengenai muqārabah, termasuk tentang persoalan räbitah. Ketiga, memojokkan golongan muda yang menganggap mereka tidak memiliki pengetahun tentang räbitah. Keempat, merangkul berbagai komponen masyarakat untuk mendukung tarekat, termasuk mendekati kaum adat dan mengambil simpati kolonial Belanda meski mereka menjajah Indonesia. Kelima, mengobarkan semangat untuk melawan kaum muda, termasuk mencela kitab-kitab rujukan mereka seperti "Zād al-Ma‘ād" karya Ibn Qayyim, al-Fatāwā karya Ibn Taymīyah yang dianggapnya sebagai kitab-kitab Wahabi. Keenam, mengukuhkan kitab-kitab yang ditulis oleh ulama-ulama terkemuka yang menjelaskan, memuji memperkuat tarekat Naqshabandīyah. Latief, Gerakan Kaum Tua di Minangkabau, 462.

62 Martin Van Bruinessen, Tarekat Naqshabandīyah di Indonesia (Bandung: Mizan, 1996), 129.

${ }^{63}$ Nama lengkapnya adalah Muhammad Dalil b. Muhammad Fatawi. Ia lahir di Bayang, Kabupaten Pesisir Selatan pada tahun 1864. Kemudian ia pindah, menetap dan wafat di kota Padang pada tahun 1923 dalam usia 59 tahun. Ia dikebumikan di belakang Masjid Gantiang kota Padang. Lihat Latief, Gerakan Kaum Tua, 464.

${ }^{64}$ Shaykh Sulaiman al-Rasuli lebih populer di Minangkabau dengan sebutan "Inyiak Canduang" karena ia tinggal di daerah Canduang, Ampek Angkek, Agam. Ia Lahir di Canduang tahun 1871 dan wafat tahun 1970 dalam usia hampir seratus tahun. Ibid., 476. Guru-guru yang menjadi tempat Shaykh Sulaiman al-Rasuli belajar juga diungkapkannya sendiri dalam karyanya yang berjudul "Kitab Pertalian Adat dan Syarak yang Terpakai di Alam Minangkabau Lareh nan Duo Luhak nan Tigo". Lihat Sulaiman al-Rasuli, Kitab Pertalian Adat dan Syarak yang Terpakai di Alam Minangkabau Lareh nan Duo Lubak nan Tigo (Bukittinggi: t.tp., 1927), 63.

${ }^{65}$ Latief, Gerakan Kaum Tua di Minangkabau, 460. 
Ketika terjadi perdebatan tentang tarekat di Padang Panjang pada tahun 1905 yang dihadiri oleh Abdul Karim Amrullah sebagai golongan muda dan golongan tua, misalnya, golongan tua menganggap remeh Abdul Karim Amrullah karena dianggap tidak memiliki pengalaman dan pengetahun tentang tarekat. Oleh karena itu, kritik yang dilontarkannya tidak dapat dipercaya. Berbeda halnya dengan Muhammad Djamil Djambek ${ }^{66}$ yang juga termasuk golongan muda, ia pernah mempelajari dan mengamalkan Tarekat Naqshabandīyah, tetapi kemudian meninggalkannya setelah mengetahui hakikat tarekat tersebut. Tapi sayangnya, penjelasan tentang hakikat Tarekat Naqshabandīyah yang ditulis Djamil Djambek terlambat sampai ke tangan penentang tarekat. Kritik Djamil Djambek tentang Tarekat Naqshabandīyah selesai ditulis pada tahun 1940, ${ }^{67}$ ketika pimpinan pembela Tarekat Naqshabandīyah telah wafat.

Berkaitan dengan persoalan räbitah atau tawassul, Djamil Djambek sependapat dengan Abdul Karim Amrullah. Djamil Djambek dalam bukunya Penerangan tentang Asal Usul Tarekat Naqshabandiyah sebagaimana yang dikutip oleh M. Sanusi Latief mengungkapkan bahwa melakukan tawassul atau räbitah itu tidak ada dasarnya dalam Islam, baik dari al-Qur'ān maupun hạdīth Nabi Muhammad yang melegitimasi praktik dalam tarekat tersebut. Tarekat itu dibuat-buat oleh orang India dan Persia, negeri yang sarat dengan pemikiran kburafät dan tabkayyul. ${ }^{68}$ Selanjutnya menurut Djamil Djambek, amalan sulük ini adalah amalan tarekat yang menyebabkan orang malas dan memandang hidup secara pesimis yang diwarisi oleh umat Islam sejak masa kejatuhan Baghdad tahun 1258. Setelah peristiwa itu, umat Islam mencari arti kehidupan beragama dalam kelompok-kelompok yang disebut tarekat itu. ${ }^{69}$

Hal baru yang dikemukan Djamil Djambek yang belum dijelaskan golongan muda lainnya adalah adanya surat Khalid Kurdi yang melarang para khalifah untuk menyuruh murid-murid tarekat meräbitah-kan diri mereka. Surat tersebut dicantumkan dan diberi penjelasan oleh Muhammad Khani (khalifah ketiga dari Khalid Kurdi yang berada pada urutan ke 32 dalam silsilah Tarekat

\footnotetext{
${ }^{66}$ Penggunaan Djambek di akhir nama Djamil Djambek karena dia suka memelihara jambang. Lihat Hamka, Ayabku, 280.

${ }^{67}$ Latief, Gerakan Kaum Tua di Minangkabau, 512.

${ }^{68}$ Ibid., 516

${ }^{69}$ Nazwar, Abmad Khatib al-Minangkabawi, 56.
} 
Naqshabandīyah) dalam bukunya al-Bayah al-Saniyah yang mengungkapkan bahwa me-räbitah-kan orang yang belum pernah mengalami fana $\vec{a}$ niscaya tidak akan menghasilkan fanä' bagi orang yang ber-sulük. Bahkan sebaliknya, akan menimbulkan malapetaka baginya. Khalid Kurdi berkata: "Oleh sebab itu, janganlah kamu mengajarkan kepada murid-muridmu untuk me-räbitah-kan rupa dirimu. Kalau wajahmu terlihat juga oleh mereka dalam bayangan pikiran mereka, maka itu hanyalah semata-mata tipu daya iblis." ${ }^{, 7}$

Muhammad Khani memberikan penjelasan tentang maksud surat itu, bahwa Khalid Kurdi melarang para khalifah dan para pengikut tarekat Naqshabandìah-Khalidiyah untuk menjadikan diri mereka sebagai räbitab ketika seseorang melakukan sulük. Oleh sebab itu, Djamil Djambek mengungkapkan keheranannya kepada para shaykh atau para khalifah Tarekat Naqshabandīyah di zaman sekarang yang masih menyuruh pengikut-pengikut mereka me-räbitah-kan murshid mereka, padahal Khalid Kurdi telah melarangnya baik dengan lisan atau melalui tulisannya. Selanjutnya, Khalid Kurdi memberikan ancaman bahwa siapa yang tidak mematuhi isi surat itu, maka dia tidak dianggap sebagai murid dan pengikutnya serta tidak dibolehkan menggunakan namanya sebagai gelar nisbijyah di ujung nama mereka. ${ }^{71}$

Kritik Abdul Karim Amrullah terhadap tarekat dalam tasawuf pada dasarnya bukanlah kritik terhadap esksistensi tasawuf itu sendiri, melainkan adanya unsur bidah dalam tradisi tarekat yang tidak pernah diajarkan oleh Rasulullah maupun sahabat beliau. Ironisnya, menurut Abdul Karim Amrullah, bidah tersebut menjadi sesuatu yang seolaholah berasal dari ajaran Islam yang harus diikuti oleh orang-orang yang ingin mendekatkan diri kepada Tuhan dalam tarekat. Tasawuf yang benar adalah tasawuf yang berdasarkan kepada nass-nass. yang terdapat dalam al-Qur'ān dengan memanfaatkan dunia untuk mencapai akhirat, bukan dengan cara melarang hal-hal yang sudah dibolehkan Allah. Tujuan Abdul Karim Amrullah sama dengan pandangan Muhammadiyah [salah satu ormas Islam terbesar di Indonesia] untuk menjaga kemurnian akidah dan kemurnian ajaran Islam $^{72}$ yang dikhawatirkan tergerus oleh aktivitas sulukk dalam tarekat seperti yang terdapat dalam ayat 87 surah al-Mā’idah tentang

\footnotetext{
${ }^{70}$ Latief, Gerakan Kaum Tua di Minangkabau, 517.

${ }^{71}$ Ibid, 518.

${ }^{72}$ Faisal Ismail, Ketegangan Kreatif Peradaban Islam: Idealisme versus Realisme (Jakarta: PT. Bakti Aksara Persada, 2003), 104
} 
kebolehan memakan makanan yang dihalalkan Allah bukan dengan cara mengharamkan memakan daging dalam waktu tertentu. ${ }^{73}$

Sebenarnya, bagi Abdul Karim Amrullah, tasawuf merupakan bagian penting dalam Islam sehingga ia sendiri dalam tafsir al-Burbānnya juga merujuk kepada tokoh-tokoh tasawuf sebagai referensi, seperti Ibrāhīm b. A'zam (w. 160 H/777 M) yang mengungkapkan perlunya memperhatikan orang-orang yang mengemis karena orang yang meminta-minta itu telah mendekatkan kita kepada Allah. Kehadiran pengemis menyebabkan kita memiliki bekal untuk sampai kepada akhirat. ${ }^{74}$ Abdul Karim Amrullah, misalnya, merujuk pendapat Ibrāhīm b. A'ẓam ketika menafsirkan surah al-Ḍuhāa ayat 10 .

Menariknya, fenomena tarekat, menurut Pemerintah Kolonial Belanda saat itu, termasuk eksistensi tarekat di Minangkabau sama posisinya dengan ajaran-ajaran Islam lainnya, sebagai bagian yang perlu diawasi. Semangat Islam yang tertanam dalam hati orang muslim dapat mengganggu kepentingan kolonialisasi di Sumatera Barat. Oleh karena itulah berbagai upaya dilakukan Belanda untuk menyingkirkan pengaruh Islam dari masyarakat setempat seperti yang juga dialami oleh Abdul Karim Amrullah ketika ia diadukan oleh golongan adat dan ulama tradisional bahwa ia telah membuat keresahan dalam masyarakat. Setelah dilakukan penelusuran siapa yang mengadukan Abdul Karim Amrullah kepada Belanda ternyata tidak ada bukti bahwa golongan adat dan golongan ulama tradisional telah mengadukannya ke Belanda, namun Belanda tetap menjatuhkan hukuman kepada Abdul Karim Amrullah dengan cara mengasingkannya ke Pulau Jawa pada tahun $1941 .{ }^{75}$

Kegiatan tarekat dengan cara mengasingkan diri untuk mendapatkan ketenangan di pelosok-pelosok atau ke sudut-sudut kota sewaktu-waktu ternyata menyusahkan dan dicurigai Belanda karena adanya pemusatan kekuatan di bawah bimbingan para guru yang dipandang sebagai orang suci. Pemusatan kekuatan tersebut sewaktu-

73 Selain surah al-Mā'idah ayat 87, surat lain yang menjelaskan bolehnya memakan makanan yang halal adalah surah al-Mu'min ayat 51:

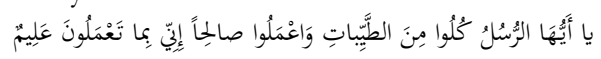

Kebolehan memakan makanan yang baik-baik juga disinggung dalam surat al-A'rāf ayat 31:

${ }^{74}$ Amrullah, al-Burhān, 40.

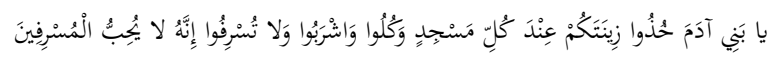

75 Usman Pelly, Urbanisasi dan Adaptasi Peranan Misi Budaya Minangkabau dan Mandailing (Jakarta: LP3ES, 1998), 35. 
waktu dapat mencetuskan pemberontakan dan perlawanan terhadap Belanda. $^{76}$

Belanda seringkali bersimpati kepada kepercayaan dan praktikpraktik sinkretistik, meskipun mereka mengganggapnya sebagai takhayyul, tetapi orang-orang yang hidup lebih ketat sesuai dengan ajaran Islam sering menimbulkan antipati dan ketakukan bagi mereka. Pegawai pemerintah Belanda cenderung menganggap bahwa semua gejala keberagamaan, khususnya orang-orang Muslim yang melakukan salat lima waktu, dianggap sebagai bentuk fanatisme yang berpotensi menimbulkan aksi subversif terhadap pemerintahan kolonial. ${ }^{77}$

\section{Penutup}

Berdasarkan pemikiran yang dikemukan Abdul Karim Amrullah di atas, jelas bahwa ia menolak melakukan räbitab karena baginya tidak adanya legalitas shar ì untuk melakukan amalan tersebut, meskipun golongan tua di Minangkabau terus berupaya untuk menghidupkan räbitah di surau-surau yang mereka pimpin. Räbitah sebagai bagian dari wasilah dipahami golongan tua sebagai media untuk sampai kepada Allah melalui wajah pengganti. Wajah pengganti yang dimaksud adalah para murshid yang mengajarkan murid-muridnya untuk sampai pada maqāmāt yang sudah ditentukan dalam masing-masing tarekat. Kritik Abdul Karim Amrullah tentang räbitah dalam tarekat di Minangkabau pada awalnya memang menimbulkan penolakan, khususnya bagi para pendiri tarekat, tapi seiring dengan berjalannya waktu, persoalan tarekat mengalami kemunduran, bahkan hal tersebut diiringi dengan memudarnya tarekat itu sendiri di daerah Minangkabau.

\section{Daftar Rujukan}

al-Khalidi, Sulaiman al-Rasuli. Qawl al-Bayān. Fort De Kock: alMatbaah al-Islamiyah, 1929.

al-Rasuli, Sulaiman. Kitab Pertalian Adat dan Syarak yang Terpakai di Alam Minangkabau Lareh nan Duo Lubak nan Tigo. Bukittinggi: t.tp., 1927.

Amrullah, Abdul Karim. 'Umdah al-Anàm fì Tlm al-Kalām. Padang: alMunir, 1916.

\footnotetext{
${ }^{76}$ Simuh, Sufisme Jawa, 66.

${ }_{77}$ Bruinessen, Tarekat Naqshabandiyah, 22.
} 
-----. Pedoman Guru Pembetulkan Kiblat Paham Keliru. Fort de Kock: Drukerij Limbago, 1930.

----. Qäti' Riqāb al-Mulhidìn fì 'Aqā'id al-Mufsidiin. Padang: Drukerij Snaperes, 1916.

Arifin, Miftah. Sufi Nusantara: Biografi Karya Intelektual dan Pemikiran Tasawnf. Yogyakarta: Ar-Ruzz Media, 2013.

Azra, Azyumardi. Jaringan Ulama Timur dan Kepulauan Nusantara Abad XVII dan XVIII (Jakarta: Kencana, 2007), 357.

-----. Pendidikan Islam: Tradisi dan Modernisasi di Tengab Tantangan Milenium III. Jakarta: Kencana, 2012.

Bruinessen, Martin Van. Tarekat Naqshabandiyah di Indonesia. Bandung: Mizan, 1996.

Chambert-loir, Hendri. Naik Haji di Masa Silam Tabun 1900-1950, Vol. 2. Jakarta: Gramedia, 1913.

Dimashqìyah, 'Abd al-Raḥmān b. Muhammad. Haqāiq Khațìah alȚariqah al-Naqshabandìyah. Riyāḍ: Dār al-Muslim, 1998.

Djamal, Murni. DR. H. Abdul Karim Amrullah: Pengarubnya dalam Gerakan Pembaruan Islam di Minangkabau pada Awal Abad ke-20, terj. Theresia Slamet. Jakarta: INIS, 2002.

Dobbin, Christine. Kebangkitan Islam dalam Ekonomi Petani yang Sedang Berubah Sumatera Tengah 1784-1847. Jakarta: INIS, 1992.

Fathurahman, Oman. Tarekat Syattariyah di Minangkabau: Teks dan Konteks. Jakarta: Prenada Media Group, 2008.

Gibb, H. R. G. dan Kramers, J.H. Shorter Encyclopaedia of Islam. Leiden: t.tp., 1953.

Halimah, Abdul Mun'im Musthofa. Jejak Amal-amal Kemurtadan. t.t.: t.tp., t.th.

Hamka. Ayabku: Riwayat Hidup DR. H. Abdul Karim Amrullah dan Perjuangan Kaum Agama di Sumatera. Jakarta: Ummida, 1982.

Ichsan, A. Sawabi dkk. Muqaddimah al-Qur'an dan Tafsimya. Jakarta:

Dewan Penyelenggara Pentafsiran al-Qur'an Departemen Agama RI, 1983.

Ismail, Faisal. Ketegangan Kreatif Peradaban Islam: Idealisme versus Realisme. Jakarta: PT. Bakti Aksara Persada, 2003.

Jābirī (al), Muhammad 'Ābid. Fahm al-Qur'ān al-Häkim: Tafsìr al-Wädịh Hasb Tartīb al-Nuru>l. Beirut: Markaz Dirāsāt al-Waḥdah alIslāmīyah, 2008. 
Kamal, Tamrin. Purifikasi Ajaran Islam pada Masyarakat Minangkabau: Konsep Pembaruan H. Abd. Karim Amrullah Awal Abad Ke-20. Padang: Angkasa Raya, 2005.

Latief, M. Sanusi. "Gerakan Kaum Tua di Minangkabau" (Disertasi-IAIN Syarif Hidayatullah, Jakarta, 1988.

Namlah (al), 'Abd al-Karìm b. 'Alī b. Muhammad. al-Muhadhdhab fi Ilm Ușül al-Figh al-Muqāran, Vol. 2. Riyad: Maktabat al-Rushd, 2008.

Navis, A.A. Alam Terkembang Jadi Guru Adat dan Kebudayaan Minangkabau. Jakarta: Temprint, 1986.

Nazwar, Akhria. Ahmad Khatib al-Minangkabawi Ilmuan Islam di Permulaan Abad Ini. Jakarta: Pustaka Panji Mas, 1983.

Pelly, Usman. Urbanisasi dan Adaptasi Peranan Misi Budaya Minangkabau dan Mandailing. Jakarta: LP3ES, 1998.

Putra, Yerri S. Minangkabau di Persimpangan Generasi. Jakarta: Insist Press, 2007.

Said, A. Fuad. Hakikat Tarekat Naqshabandìyah. Jakarta: PT. Al-Husna Zikra, 1996.

Simuh. Sufisme Jawa: Transformasi Tasawuf Islam ke Mistik Jawa. Jakarta: Narasi, 2016.

Syam, Nur. Tarekat Petani Fenomena Tarekat Syattariyah Lokal. Yogyakarta: LKiS, 2013.

Thohir, Ajid. Gerakan Politik Kaum Tarekat: Telaah Historis Gerakan Politike Antikolonialisme Tarekat Qadiriyah-Naqshabandiyah di Pulau Jawa. Bandung: Pustaka Hidayah, 2002.

Yunus, Mahmud. Tafsir Qur'an Karim. Jakarta: Mahmudiah, 1957. 